with 40 in 1840. According to Dr. Birnbaum, de. population in France is due to individual and voluntary limitation of births, whether this limitation is due to anticonceptional measures or to criminal abortions, of which latter more than 300,000 are carried out on married women in France every year.

\section{Retail-Store Training}

A Bulletrn by K. B. Haas (Vocational Division Bulletin No. 205, Business Education Series No. 12) which has been issued by the Office of Education, United States Department of the Interior, under the title "Co-operative Part-Time Retail Training Programmes", reviews the history and progress of retailstore training programmes. It discusses the need for training programmes in secondary schools and extension classes and describes the kinds of training programmes which have prospects of success. Proved methods for promoting, initiating, co-ordinating, supervising and teaching the various types of retailtraining courses in different communities are indicated as well as both the factors contributing to the success of such programmes and mistakes which have been made. The qualifications necessary for teachers of such subjects are discussed, and emphasis is placed on the co-operative part-time type of instruction on the secondary level.

\section{The Colonial Service: Recent Appointments}

THE following appointments and promotions in the Colonial Service have recently been made: P. G. Coleman, agricultural officer, Malaya; M. D. ffrenchMullen, agricultural officer, Fiji; F. B. Leech, veterinary officer, Nyasaland; G. C. L. Bertram, chief fisheries officer, Palestine; C. L. Gulliver, meteorological assistant, Nigeria; A. S. Richardson (deputy director of Agriculture, Uganda), director of agriculture, Nyasaland; D. H. Hodgson (conservator of forests), deputy director of forests and deputy adviser on forestry, Malaya; H. E. C. Lushington (assistant conservator of forests), senior assistant conservator of forests, Ceylon; J. G. Watson (deputy director of forests and deputy advisor on forestry), director of forests and adviser on forestry, Malaya.

\section{The Night Sky in October}

THe moon is new on October 1 and 30 and full on October 16. Jupiter and Saturn are in conjunction with the moon on October 18d. 0h. and Venus on 28d. 4h. U.T. The 4th magnitude star, $\alpha$ Cancri, is occulted on October 25, the disappearance occurring at $1 \mathrm{~h} .48 \cdot 3 \mathrm{~m}$. (at position angle $116^{\circ}$ from the north point) and the reappearance at $2 \mathrm{~h} .49 \cdot 8 \mathrm{~m}$. at position angle $267^{\circ}$. Jupiter and Saturn, still close together, rise before $18 \mathrm{~h}$. in mid-October. These two planets are in conjunction with one another on October 11 at $23 \mathrm{~h}$., but their closest approach $\left(1 \cdot 2^{\circ}\right)$ occurs on October 19. Close groupings of Jupiter's four inner satellites can be seen at $0 \mathrm{~h} .15 \mathrm{~m}$. on October 3, 4, 11,12 and 19 (all to the eastward side), 21, 28 and 29. Examples of wide separation occur on October $6,8,15$ and 31 . Venus, the brilliant planet rising about four hours before the sun, is close to Regulus on October 6 and near $\beta$ Virginis on October 29 . Conjunction with Neptune is on October 29 at $21 \mathrm{~h}$. The Orionid meteors reach their maximum frequency about October 19, the radiant point being north, following $\alpha$ Orionis (Betelgeuse).

The new moon on October 1 is associated with a total eclipse of the sun, the path of totality, some 120 miles wide, crossing Brazil, the South Atlantic to South Africa. The duration on the Brazilian coast will be 5 minutes; north-east of East London, South Africa, the duration is $3 \mathrm{~min} .24 \mathrm{sec}$. A general article referring to arrangements for observing the eclipse appears on p. 422 of this issue.

\section{Announcements}

Among the changes in the Schedule of Reserved Occupations recently announced is the statement that scientific and research workers may now volunteer for general service in the armed forces irrespective of age, provided that consent is obtained from the Committee for Scientific Research of the Central Register Advisory Council.

DURING the continuance of the present disturbed conditions, the library of the Chemical Society at Burlington House, London, will be closed on Saturdays. So far as circumstances permit, it will be open on other weekdays from 10 a.m. until 5 p.m.

THE Rockefeller Foundation has given $£ 1,000$ to the Royal Society of Medicine for the preservation of its library. It is proposed to evacuate to a suitable house a number of the older and irreplaceable periodicals. A member of the library staff will accompany them and will be in telephonic communication with the library in London.

The fourth Pan-American Congress of the Red Cross will be held at Santiago, Chile, during December 5-14 under the direction of General L. Brieba, president of the Central Committee of the Red Cross in Chile.

MANY valuable zoological collections recently gathered in Central America for the British Museum are being housed in the Field Museum of Natural History, Chicago. After an expedition headed by Ivan T. Sanderson, of Belize, British Honduras, had completed its work of collecting mammals, reptiles and various invertebrate animals in Central America, the War made it unsafe to ship them to England. The Field Museum, therefore, offered its hospitality, and the first large instalment of Mr. Sanderson's material has recently arrived there. Some of it is to be classified there, at his request, and ultimately some division of the collections will be made between the Field Museum and the British Museum.

THE International Commission on Zoological Nomenclature has commenced the publication of the Opinions rendered by the Commission, vol. 2, Opinions 134-136. Copies may be obtained from the Commission, c/o Royal Entomological Society of London, 41 Queen's Gate, South Kensington, London, S.W.7. 